ISSN 0258-7122

Bangladesh J. Agril. Res. 36(3) : 389-396, September 2011

\title{
VARIATIONS IN DIFFERENT ISOLATES OF Rhizoctonia solani BASED ON TEMPERATURE AND pH
}

\author{
B. K. GOSWAMI ${ }^{1}$, M. M. RAHAMAN ${ }^{2}$, A. K M. A. HoQUE ${ }^{3}$ \\ K. BHUYAN ${ }^{4}$ AND I. H. MIAN ${ }^{5}$
}

\begin{abstract}
An experiment was conducted to find out variation in isolated Rhizoctonia solani based on radial mycelial growth and sclerotial production. Five isolates of Rhizoctonia solani representing five clusters group were selected and were grown at different levels of temperature and $\mathrm{pH}$ on potato dextrose agar (PDA). It was observed that optimum temperature and $\mathrm{pH}$ for growth and scierotial production varied among the isolates. The rates of growth and sclerotial formation were not uniform at the same levels of the two growth factors. The maximum mycelial growth of all isolates was found at $30^{\circ} \mathrm{C}$. At $35^{\circ} \mathrm{C}$, only GAZ-9 and GAZ-18 showed initiation of growth, but the rate was very slow. The optimum temperature for sclerotial production of the isolates GAZ-9, JES16 , GAZ-18 SYL-26 was $30^{\circ} \mathrm{C}$ and for the isolate $\mathrm{DIN}-8$ was $25^{\circ} \mathrm{C}$. The optimum $\mathrm{pH}$ for maximum radial growth was 6 for DIN-8 and 7 for other four isolates. The maximum number of sclerotia was produced by DIN-8, GAZ-9,

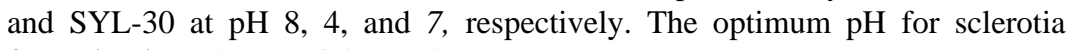
formation in JES-16 and GAZ-18 was $\mathrm{pH} 6$.
\end{abstract}

Keywords: Rhizoctonia solani, variations, temperature, $\mathrm{pH}$.

\section{Introduction}

Rhizoctonia solani Kuhn (Teleomorph: Thanatephorus cucumeris) is a widespread and destructive fungal pathogen of many plant species (Menzies 1970). Different types of disease symptoms like damping off, root, crown and stem rot, sheath blight, etc. are caused by the pathogen. It is a complex pathogen with great variations among the isolates in terms of myclial colour, zonation, type, and number of scierotia, size of aerial mycelium, growth rate, saprophytic behaviour, enzyme production and pathogenicity (Hyakumachi et al. 1988). The fungal species is not a discrete taxonomic unit, rather a "collective species" composed of many related but apparently genetically isolated groups. Many criteria have been used to delineate subgroups of the species $R$. solani. Earlier methods of sub grouping included differences in colony morphology, host range virulence and so on, whereas recent methods include biochemical and molecular techniques (Carling et al., 1994). Grouping of isolates of R. solani based on hyphal anastomosis reaction have been reported by Anderson (1982). Thirteen

\footnotetext{
${ }^{1 \& 2}$ Principal Scientific Officer and Scientific Officer, Plant Pathology Division, RARS, BARI, Jamalpur, ${ }^{3}$ Research Student, Bangabandhu Sheikh Mujibur Rahman Agricultural University (BSMRAU), Gazipur, ${ }^{4}{ }^{5}$ Professor, BSMRAU, Gazipur, Bangladesh.
} 
anastomosis groups (AGS) of $R$. solani have been identified by Carling et al., 2003. This method is most helpful to plant pathologists although doubts remain about the usefulness of such growing. Some isolates those are very identical in behaviour and appearances do not anastomos with one another. Many isolates could not fit into any group though they have identical characters. Furthermore, grouping by anastomosis does not always correspond to grouping by colony morphology pathogenicity or other physiological features (Baker et al., 1984; Carling, 1996). Beyond the recognized ways to group isolates of $R$. solani taxonomically, variation of growth character within different temperature and $\mathrm{pH}$ have been reported by Chang (1985). The optimal temperature for growth of the fungus is $23-28{ }^{\circ} \mathrm{C}$, although lower and higher optima have been reported for various isolates (Abe and Tsuboki, 1978).

In Bangladesh, many crops are attacked by $R$. solani. It causes sheath blight in rice, black scurf in potato, damping off in tobacco, cotton, cabbage, cauliflower, brinjal, indian spinach and chilli (Anon., 1969; Ahmed and Hossain 1985; Talukder, 1974). In the country, no information is available regarding the variability in $R$. solani, especially variation of the isolates in different temperature and $\mathrm{pH}$ regimes. Therefore, the present piece of research was conducted to find out variations in different isolates of $R$. Solani based on different temperature and $\mathrm{pH}$ regimes on culture media.

\section{Materials and Method}

A study was undertaken to find out the variations among the isolates of $R$. solani on the basis of mycelial growth and scierotium formation at different temperature and $\mathrm{pH}$ levels. Isolates of $R$. solani were collected from different diseased plant parts and soils from 22 districts of Bangladesh. For isolation and identification, standard procedures were followed as described by Bhuiyan (1994). After identification, the isolates were designated using first three letters of the district from where they were collected and serial numbers were given in accordance with the date of collection. Altogether 50 isolates were collected and stored in test tube slant at $10^{\circ} \mathrm{C}$.

The collected isolates were grown on PDA in $9 \mathrm{~cm}$ diameter Petri dishes with four replications and incubated for 4 weeks at $25 \pm 1^{\circ} \mathrm{C}$. Observation was made regularly and data on the myccelial growth rate/24 hour, structure, zonation, and colour of the colony, number of sclerotia/ $\mathrm{cm}^{2}$, colour of scierotia, shape and size of sclerotia, days to scierotial initiation and the formation patterns of scierotia were collected. Variations among the isolates based on morphological characters was analyzed following cluster analysis for classifying 50 isolates into more or less homogeneous groups. The collected isolates were classified into five cluster group. Finally five isolates, namely DIN-8, GAZ-9, JES-16, GAZ-18 and SYL- 
30 were selected from five different cluster groups to find out the variations at different levels of temperature and $\mathrm{pH}$.

Five levels of temperatures viz. $15,20,25,30,35^{\circ} \mathrm{C}$ were maintained in the trial. Fifteen milliliter of PDA was dispensed into each of the Petri dish $(9 \mathrm{~cm}$ diameter). The $\mathrm{pH}$ of the medium was adjusted at 6.5. Mycelial discs of $4 \mathrm{~mm}$ diameter were cut aseptically with flame sterilized cork borer from the margin of 2 days old culture of five different $R$. solani isolates. One disc was placed in the center of individual Petri dish. Four dishes were used for each isolates. After inoculation, the petri dishes were incubated in incubators maintaining the five different temperature levels. The petri dishes were arranged in the incubators following completely randomized design (CRD).

Five different levels of $\mathrm{pH}$ viz. 4.0, 5.0, 6.0, 7.0, and 8.0 were maintained to study the isolates variation at different $\mathrm{pH}$. The $\mathrm{pH}$ level was adjusted by adding HCI or NaOH before solidifying the PDA media with continuous stirring. Procedure for pouring of PDA media and inoculation of mycelial discs with five different isolates were same as mentioned before. After inoculation, the Petri dishes were incubated at $25^{\circ} \mathrm{C}$. Four dishes were used for treatment. The Petri dishes were arranged in the incubators following CRD.

From both the trials of temperature and $\mathrm{pH}$, the data on radial colony growth and number of sclerotia/ $\mathrm{cm}^{2}$ of the colony were recorded. Radial colony growth was measured by averaging the two diameters taken at right angles for each colony when mycelial growth of some isolates reached the edge of the Petri plates. Number of sclerotia of the colony was recorded by averaging the data of three different area of a Petri dish after two weeks of incubation. Data were analyzed statistically using MSTAT-C computer programme and means were compared using DMRT.

\section{Results and Discussion}

\section{Effect of temperature on colony growth}

All the five tested isolates of $R$. solani grew well on PDA at the temperature range from 25 to $30^{\circ} \mathrm{C}$. Maximum growth of colony of all isolates on PDA was found at $30{ }^{\circ} \mathrm{C}$, which was followed by $25{ }^{\circ} \mathrm{C}$. The colony diameter of the isolates GAZ-9, GAZ-18, and JES-16 at $30{ }^{\circ} \mathrm{C}$ was statistically similar, but significantly higher as compared to DIN-8 and SYL-30 which were also statistically similar in colony diameter. At $25^{\circ} \mathrm{C}$, colony diameter of JES- 16 and GAZ-1 8 was not significantly different. Two isolates, namely GAZ-9 and GAZ18 had a minimum growth at $35^{\circ} \mathrm{C}$, but other isolates failed to grow at $35^{\circ} \mathrm{C}$. A considerable growth was observed at 15 and $20^{\circ} \mathrm{C}$ in case of all the tested isolates (Table 1). 
Table 1. Radial colony growth of five isolates of $R$. solani on PDA at five different levels of temperature.

\begin{tabular}{c|c|c|c|c|c}
\hline \multirow{2}{*}{$\begin{array}{c}\text { Temperature } \\
\left({ }^{\circ} \mathrm{C}\right)\end{array}$} & \multicolumn{5}{|c}{ Colony diameter $(\mathrm{cm})$ of $R$. solani on PDA } \\
\cline { 2 - 6 } & DTN-8 & GAZ-9 & JES-16 & GAZ-18 & SYL-30 \\
\hline \multirow{2}{*}{15} & $1.40 \mathrm{j}$ & $1.70 \mathrm{~h}$ & $1.50 \mathrm{hi}$ & $0.90 \mathrm{k}$ & $1.53 \mathrm{hij}$ \\
& $(1.38)$ & $(1.48)$ & $(1.41)$ & $(1.18)$ & $(1.42)$ \\
\multirow{2}{*}{20} & $1.47 \mathrm{ij}$ & 2.10 & $2.0 \mathrm{~g}$ & $1.63 \mathrm{hi}$ & $1.67 \mathrm{hi}$ \\
& $(1.40)$ & $(1.610$ & $(1.58)$ & $(1.46)$ & $(1.47)$ \\
\multirow{2}{*}{25} & $3.10 \mathrm{f}$ & $6.20 \mathrm{~b}$ & $5.60 \mathrm{c}$ & $5.53 \mathrm{c}$ & $3.53 \mathrm{e}$ \\
& $(1.90)$ & $(2.59)$ & $(2.47)$ & $(2.46)$ & $(2.01)$ \\
& $4.33 \mathrm{~d}$ & $8.47 \mathrm{a}$ & $8.20 \mathrm{a}$ & $8.13 \mathrm{a}$ & $4.53 \mathrm{~d}$ \\
30 & $(2.20)$ & $(2.99)$ & $(2.95)$ & $(2.94)$ & $(2.25)$ \\
\hline \multirow{2}{*}{35} & $0.0 \mathrm{n}$ & 0.531 & $0.00 \mathrm{n}$ & $0.27 \mathrm{~m}$ & 0.00 \\
& 0.71 & $(1.01)$ & $(0.71)$ & $(0.87)$ & $(0.71)$ \\
\hline
\end{tabular}

Values within columns and rows having common letter do not differ significantly $(\mathrm{P}=0.05)$ Figures with parenthesis indicate square root transformed values.

\section{Effect of temperature on sclerotia formation}

All isolates except DIN-8 produced the highest number of sclerotia at $30{ }^{\circ} \mathrm{C}$, which was followed by 25 and $20^{\circ} \mathrm{C}$. The differences in sclerotia production by DIN-8, GAZ-9, GAZ-18, and SYL-30 at 20,25 , and $30{ }^{\circ} \mathrm{C}$ were significant. The number of sclerotia production at 20 and $25^{\circ} \mathrm{C}$ was statistically similar but significantly lower as compared to $30^{\circ} \mathrm{C}$ in JES-16. No sclerotium was produced by the isolates DIN-8, JES-16, and SYL-30 at $35{ }^{\circ} \mathrm{C}$ as there was no growth of fungus. The other two isolates produced only a minimum number of sclerotia at $35^{\circ} \mathrm{C}$ where growth was also minimum. At $15^{\circ} \mathrm{C}$ maximum of 9.0 sclerotia $\mathrm{cm} 2$ was found in DIN-8, which was statistically similar to JES-16 but significantly higher as compared to other four isolates (Table 2). Results of the experiment indicated that $30^{\circ} \mathrm{C}$ was the best temperature for the production of sclerotia in $R$. solani, which was followed by $25^{\circ} \mathrm{C}$. The same levels of temperature were better for colony growth of the fungus. It was found that there were variations among the isolates regarding colony diameter and sclerotia formation on PDA at the same levels of temperature. It also suggested the existence of genetic variability among the isolates of R. solani. 
Table 2. Variations in sclerotium formation in five isolates of $R$. solani at five different levels of temperature.

\begin{tabular}{|c|c|c|c|c|c|}
\hline \multirow{2}{*}{$\begin{array}{l}\text { Temperature } \\
\quad\left({ }^{\circ} \mathrm{C}\right)\end{array}$} & \multicolumn{5}{|c|}{$\begin{array}{l}\text { No. of sclerotia produced by } R \text {. solani on PDA }\left(\mathrm{cm}^{2}\right) \text { at different } \\
\text { temperature levels }\end{array}$} \\
\hline & D1N-8 & GAZ-9 & JES-16 & GAZ-18 & SYL-.30 \\
\hline 15 & $\begin{array}{l}9.0 \mathrm{e} \\
(3.08)\end{array}$ & $\begin{array}{l}3.59 h i \\
(2.02)\end{array}$ & $\begin{array}{l}\text { 8.6ef } \\
(3.01)\end{array}$ & $\begin{array}{l}1.30 \mathrm{j} \\
(1.34)\end{array}$ & $\begin{array}{l}1.30 \mathrm{j} \\
(1.34)\end{array}$ \\
\hline 20 & $\begin{array}{l}\text { l1.0de } \\
(3.39)\end{array}$ & $\begin{array}{l}7.33 f g \\
(2.79)\end{array}$ & $\begin{array}{l}\text { 11.3de } \\
(3.44)\end{array}$ & $\begin{array}{l}2.33 \mathrm{ij} \\
(1.68)\end{array}$ & $\begin{array}{l}1.63 \mathrm{j} \\
(1.46)\end{array}$ \\
\hline 25 & $\begin{array}{l}15.0 \mathrm{c} \\
(3.94)\end{array}$ & $\begin{array}{l}17.2 \mathrm{c} \\
(4.21)\end{array}$ & $\begin{array}{l}14.3 \mathrm{~cd} \\
(3.85)\end{array}$ & $\begin{array}{l}5.27 g h \\
(2.40)\end{array}$ & $\begin{array}{l}\text { 4.0hi } \\
(2.12)\end{array}$ \\
\hline 30 & $\begin{array}{l}11.3 \mathrm{c} \\
(3.44)\end{array}$ & $\begin{array}{l}33.0 \mathrm{a} \\
(5.79)\end{array}$ & $\begin{array}{l}26.6 b \\
(5.21)\end{array}$ & $\begin{array}{l}\text { l1.0de } \\
(3.39)\end{array}$ & $\begin{array}{l}10.0 \mathrm{ef} \\
(3.24)\end{array}$ \\
\hline 35 & $\begin{array}{l}0.00 \mathrm{k} \\
(0.71)\end{array}$ & $\begin{array}{l}1.30 \mathrm{j} \\
(1.34)\end{array}$ & $\begin{array}{l}0.00 \mathrm{k} \\
(0.71)\end{array}$ & $\begin{array}{l}\text { l.30j } \\
(1.34)\end{array}$ & $\begin{array}{l}0.00 \mathrm{k} \\
(0.71)\end{array}$ \\
\hline
\end{tabular}

Values within different columns and rows having common letter do not differ significantly $(\mathrm{P}=0.05)$. Figures with parenthesis indicate square root transformed values.

Similar results were also reported by Band et al. (1996) and Nelson et al. (1996). Kaminski and Verma (1985) found a variable response of different $R$. soloni isolates at different levels of temperatures. The optimum temperature for mycelial growth on PDA of four AG 2-1 isolates was $24^{\circ} \mathrm{C}$ and that of AG-4 was $26^{\circ} \mathrm{C}$. The AG2 -1 isolates exhibited some growth at very lower temperature but none at $36^{\circ} \mathrm{C}$ and not at very lower temperature. These observations illustrated that the responses of different $R$. solani isolates were different. So $R$. Solani isolates are variable on the basis of growth rate and sclerotia formation at selected temperature.

\section{Effect of pH on colony growth}

All five tested isolates of $R$. solani grew well on PDA medium at all levels of $\mathrm{pH}$ within the range of 4-8. The highest colony growth was obtained at $\mathrm{pH} 7$ in case of all the isolates except for isolate DIN-8 where best growth was observed at $\mathrm{pH}$ 6. In case of isolate DIN-8, the colony diameter was identical at $\mathrm{pH} 6$ and 7 and also at $\mathrm{pH} 5$ and 8. The growth of isolate GAZ-9 was indentical at $\mathrm{pH}$ 6, 7 and; $\mathrm{pH}$ 5, 6 and 8; $\mathrm{pH} 4,5$ and 6. In case of isolate JES-16, the highest colony growth was observed at $\mathrm{pH} 7$ where the growth at $\mathrm{pH} 6$ and 8 were statistically similar. Significantly the highest colony diameter was observed in the isolate SYL-30 at $\mathrm{pH} 7$ followed by $\mathrm{pH} 6,8,5$, and 4 . In case of all the tested isolates, significantly lowest growth was observed at $\mathrm{pH} 4$ (Table 3). 


\section{Effect of pH on sclerotia formation}

In case of the isolate DIN-8, the highest number of sclerotia was found at $\mathrm{pH} 8$, which was followed by $\mathrm{pH} 7,6,5$, and 4 (Table 4). In GAZ-9, the trend of sclerotia production was completely reverse with the highest number at $\mathrm{pH} 4$ and the lowest at $\mathrm{pH} 8$.

Table 3. Variations in colony growth in five isolates of $R$. solani on PDA at five different levels of $\mathbf{p H}$.

\begin{tabular}{l|llllll}
\hline \multirow{2}{*}{$\mathrm{pH}$ level } & \multicolumn{5}{|c}{ Colony diameter (cm) of $R$. solani on PDA medium } \\
\cline { 2 - 6 } & \multicolumn{1}{|c}{ DIN-8 } & \multicolumn{1}{c}{ GAZ-9 } & \multicolumn{1}{c}{ JES-16 } & GAZ-18 & \multicolumn{1}{c}{ SYL-30 } \\
\hline 4 & $4.79 \mathrm{k}$ & $6.94 \mathrm{~g}$ & $6.50 \mathrm{~h}$ & $5.00 \mathrm{k}$ & $4.10 \mathrm{~L}$ \\
5 & $6.00 \mathrm{i}$ & $7.05 \mathrm{fg}$ & $7.10 \mathrm{efg}$ & $5.50 \mathrm{j}$ & $7.07 \mathrm{fg}$ \\
6 & $6.60 \mathrm{~h}$ & $7.30 \mathrm{dfg}$ & $7.57 \mathrm{~cd}$ & $6.03 \mathrm{i}$ & $7.50 \mathrm{~cd}$ \\
7 & $6.40 \mathrm{~h}$ & $7.47 \mathrm{~d}$ & $8.07 \mathrm{ab}$ & $7.50 \mathrm{~d}$ & $8.10 \mathrm{a}$ \\
\hline 8 & $6.0 \mathrm{li}$ & $7.27 \mathrm{def}$ & $7.80 \mathrm{bc}$ & $7.27 \mathrm{def}$ & $7.40 \mathrm{de}$ \\
\hline
\end{tabular}

Values within a column having common letter do not differ significantly $(\mathrm{P}=0.05)$

Similar trend like JES-16 for the production of sclerotia was observed in case of the isolate GAZ-18. In case of the isolate SYL-30, the highest number of sclerotia was produced at $\mathrm{pH} 7$ followed by $\mathrm{pH}$ 6,8,5, and 4 . Among the tested isolates, the highest number of sclerotia was produced by the isolate DIN-8 at $\mathrm{pH}$ 6 and GAZ-18, SYL-30, JES-16, and GAZ-9 at pH 7 (Table 4).

Table 4. Variations in sclerotium formation in five isolates of $R$. solani on PDA at five different levels of $\mathrm{pH}$

\begin{tabular}{l|l|l|l|l|l}
\hline \multirow{2}{*}{$\mathrm{pH}$ level } & \multicolumn{5}{c}{ No. of sclerotia $\left(\mathrm{cm}^{2}\right)$ produced by $R$. solani on PDA } \\
\cline { 2 - 6 } & \multicolumn{1}{|c}{ DIN-8 } & \multicolumn{1}{c}{ GAZ-9 } & \multicolumn{1}{c}{ JES-16 } & GAZ-18 & \multicolumn{1}{c}{ SYL-30 } \\
\hline 4 & $15.3 \mathrm{~h}$ & $11.0 \mathrm{hij}$ & $2.00 \mathrm{k}$ & $27.6 \mathrm{~g}$ & $13.6 \mathrm{hi}$ \\
5 & $34.3 \mathrm{efg}$ & $6.67 \mathrm{ijk}$ & $8.00 \mathrm{ijk}$ & $39.0 \mathrm{de}$ & $27.6 \mathrm{~g}$ \\
6 & $41.0 \mathrm{de}$ & $4.67 \mathrm{jk}$ & $17.3 \mathrm{~h}$ & $82.3 \mathrm{~b}$ & $34.0 \mathrm{~g}$ \\
7 & $75.0 \mathrm{c}$ & $3.33 \mathrm{k}$ & $10.67 \mathrm{hij}$ & $43.6 \mathrm{~d}$ & $36.6 \mathrm{ef}$ \\
\hline 8 & $97.6 \mathrm{a}$ & $3.00 \mathrm{k}$ & $7.67 \mathrm{ijk}$ & $35.0 \mathrm{ef}$ & $31.6 \mathrm{fg}$ \\
\hline
\end{tabular}

Values within row and column having common letter do not differ significantly ( $\mathrm{P}=0.05)$

Results of the experiment revealed that the optimum and best $\mathrm{pH}$ level for colony growth and sclerotia production in five isolates of $R$. solani varied widely. Isolate DIN- 8 produced maximum of 97.6 sclerotia/ $/ \mathrm{cm}^{2}$ whereas isolates GAZ-9 produced only 11.0 sclerotia/ $\mathrm{cm}^{2}$. Besides the highest number of 82.3 sclerotia 
was produced by GAZ-18. Based on the variations in colony growth and sclerotia production among the five isolates. It might be concluded that there was appreciable variability among the isolates of $R$. solani and both the characters were genetically controlled.

Similar results have also been reported by many other investigators (Gangopadhyay and Grover, 1984; Sharma and Chowdhury, 1984; Chang, 1985 and Mercelo and Vega, 1988). Kobayashi (1985) found a direct relationship between relative hyphal growth of R. solani and soil pH. Chang (1985) found that both mycellial growth and sclerotial formation of R. solani AG-1 was maximal at $\mathrm{pH}$ 7. Sharma and Chowdhury (1984) found that low incidence of R. solani in cauliflower at neutral $\mathrm{pH}$ than in those with $\mathrm{pH} 7.4$-8.5. Mercelo and Vega (1988) observed that optimum condition for $R$. solani was in $\mathrm{pH}$ 6-6.5. These variable results might be due to existence of variability among the isolates of $R$. solani which supported the findings of the present investigation.

\section{References}

Abe H. and K.Tsuboki. 1978. Anastomosis groups of isolates of Rhizoctonia solani Kuhn from potatoes. Bulleting of Hokkaido Prefectural Agricultural Experiment Station 40:61-70.

Ahmed, H.U. and M. M. Hossain. 1985. Crop disease survey and establishment of a herbarium at BARI. 107pp.

Anderson, N. A. 1982. The genetics and pathology of Rhizoctonia solani. Annual Review of Phytopathol. 20:329-347.

Anonymous. 1969. Major diseases of important crops and their remedies. Agricultural information services. Directorate of Agriculture, Dhaka 1-28 pp.

Baker, R. Y. Elad and I . Chet. 1984. The controlled experiment in the scientific method with special emphasis on biological control. Phytopathol. 74: 1019-1021.

Band, R.E., D.E. Caning and B.G. Mullinix. 1966. Characterization and comparison of isolates of Rhizoctonia solani AG-7 from Arkansas, Indiana and Japan and select AG-4 isolaes. Plant Disease 80(12). 1421-1424.

Bhuiyan, M. K. A. 1994. Pathological and physiological study of Rhizoctonia oryzae causing rice bordered sheath spot disease. A Ph.D thesis submitted to the Department of Plant Pathology, Kynshu University, Fukuoka, Japan, L39pp.

Carling, D.E., C. S. Rothrock, G. C. MacNish, M. W. Sweetingham, K. A. Brainard and S. W. Winters. 1994. Characterization of anastomosis group 11 (AG-i 1) of Rhizoctonia solani. Phytopathology 84 (12): 1387-1392.

Carling, D.E. 1996. Grouping of $R$. solani by hyphal anastomos reaction. In Rhizoctonia specices: Taxonomy, Molecular biology, Ecology, Pathology and Disease control. Pages: 37-47. Khiewer Academic Publisher, Netherlands. 
Carling D.E., E. E. Baird, R. D. Gitaitis, K. A. Brainard and S. Kunina. 2003. Characterization of AG-13, a newly reported anastomosis group of Rhizoctonia solani. Phytopathol. 92: 893-899.

Chang, Y.C. 1985. Effect of temperature, $\mathrm{pH}$ and water potential on mycelial growth and sclerotial formations of Rhizoctonia solani AG-I. J. Agric, Res. China. 34 (4): 454463.

Gangopadhyay, S. and R. K. Grover. 1984. Efficiency of fungitoxicants on the control of root-rot of cowpea caused by mixed inocula of Rhizoctonia solani. Indian J. Mycol. Plant Pathol. 14(1): 57-68.

Hyakumachi, M., T.Y. Mushika, Y. Ogosi, T. Toda, K. Kageyama and T. Tsuge. 1988. Characterization of new cultural type of $R$. solani AG-2-2 isolated from warm season turf grass and its genetic differentiation from other cultural type. Plant Pathol. 47: 1-9.

Kaminski, D. A. and P. R.Verma. 1985. Cultural Characteristics, Virulence and in vitro temperature effect on mycelial growth of Rhizoctonia isolates from rape seed. Can. J. Plant Pathol. 7 (3): 256-26 1.

Kobayashi, W.H. 1985. Natural suppression of soil borne plant diseases. Plant protection Bulletion, Taiwan 27(3). 17 1-178.

Marcelo J. C. and M.Vega, 1988. The effect of temperature $\mathrm{pH}$ and relative humidity on the biology Thanatephorus cucumeris. Ciencia-Y-Technica-en-ha Agriocultura Arroz 11(2): 3-80.

Menzies J. D. 1970. Introduction: The first century of Rhizoctonia solani. In: Parameter JR Jr (ed) Rhizoctonia solani, Biology and Pathology (pp 3-5) University of California Press, Berkeley.

Nelson, B., T. Helms, T. Christianson and I. Kural. 1996. Characterization and pathogenicity of Rhizoctonia from soybean. Plant Disease. 80 (1): 74-80.

Sharma, K. C. and. B. Chowdhury. 1984. Epidemiology of cauliflower within different soils in Jammu. Indian J. Plant Pathol. 2(1): 78-79.

Talukder, M.J. 1974. Plant diseases in Bangladesh. Bangladesh J. Agric. Res. 1(I): 6 1-83. 